\title{
A comparison of two methods for the immunoassay of intrinsic factor
}

\author{
K. D. BARDHAN, A. G. WANGEL, AND SHEILA T. CALlENDER \\ From the Nuffield Department of Clinical Medicine, \\ The Radcliffe Infirmary, Oxford
}

SYNOPSIS The intrinsic factor content of 263 samples of gastric juice was determined by immunoassay using charcoal absorption and by immunoelectrophoresis on acrylamide gel. There was good correlation between the results of the two techniques and, with a few exceptions, both made it possible to predict which patients would have malabsorption of radioactive vitamin $\mathbf{B}_{\mathbf{1 2}}$.

Of the two methods, immunoassay using charcoal absorption generally gave the higher readings. Further study showed that this could not be attributed to the recognized difference in the principles of the two methods but that it was more likely to be due to the dissimilarity of the experimental conditions.

The two commonly used methods for immunoassay of intrinsic factor are the charcoal absorption assay (Ardeman and Chanarin, 1963) and electrophoresis on starch gel (Jeffries and Sleisenger, 1963). Recently, Bardhan, Callender, and Spray (1966) have modified the latter technique by substituting acrylamide gel for starch gel to produce a quicker and more accurate assay system.

In this paper the results of immunoassay of intrinsic factor using charcoal absorption are compared with those obtained by immunoelectrophoresis on acrylamide gel.

\section{METHODS}

Gastric juice was collected as previously described (Wangel and Callender, 1965a). Specimens were collected after an overnight fast, during basal conditions, and after stimulation of gastric secretion.

The stimulants used were histamine acid phosphate $0.04 \mathrm{mg}$. $/ \mathrm{kg}$. subcutaneously in 68 subjects, and a combination of gastrin I and II in a dose of 3 Leo units per kilogram intramuscularly (Leo Laboratories, Copenhagen) in 31 subjects. One subject received 15 units of soluble insulin intravenously, resulting in a fall of the blood sugar to less than $20 \mathrm{mg}$. per $100 \mathrm{ml}$. after 30 minutes, and one received $25 \mathrm{mg}$. of methacholine (acetyl- $\beta$ methylcholine chloride) subcutaneously in three divided does at intervals of 15 minutes (Jeffries and Sleisenger, 1965) as the gastric stimulant.

IMMUNOELECTROPHORESIS This was carried out on

Received for publication 30 March 1967. acrylamide gel as described previously (Bardhan et al., 1966). In this assay normal serum containing antibody to intrinsic factor is added to a mixture of gastric juice and ${ }^{57} \mathrm{Co}-\mathrm{B}_{12}$ which has been previously incubated. Intrinsic factor-vitamin $B_{12}$ complex migrates anodally during electrophoresis; combination with antibody prevents this migration.

IMMUNOASSAY USING CHARCOAL ABSORPTION This was done according to the principle of Ardeman and Chanarin (1963) as previously described (Wangel and Callender, 1967). ${ }^{58} \mathrm{Co}_{-\mathrm{B}_{12}}$ was added to mixtures of gastric juice plus normal serum and gastric juice plus serum containing antibody to intrinsic factor. The unbound vitamin was removed by absorption with activated charcoal.

In both assay methods, the ratio of radioactive vitamin $B_{12}$ to gastric juice was the same, i.e., $400 \mathrm{~m} \mu \mathrm{g}$. vitamin $B_{12}$ to $1 \mathrm{ml}$. gastric juice neutralized to $\mathrm{pH} 7 \cdot 0$. The final results were corrected for the dilution resulting from neutralization of the gastric juice with $N \mathrm{NaOH}$.

\section{RESULTS}

With a few exceptions there was good correlation between the results of the two methods for specimens of gastric juice collected after an overnight fast, during basal conditions, and after stimulation with histamine or gastrin (Fig. 1). The agreement between the two methods was closest for measurements made on specimens collected after stimulation (Table I).

The subjects were divided on the basis of acid secretion in the hour following stimulation into the following groups: those with achlorhydria, those who 


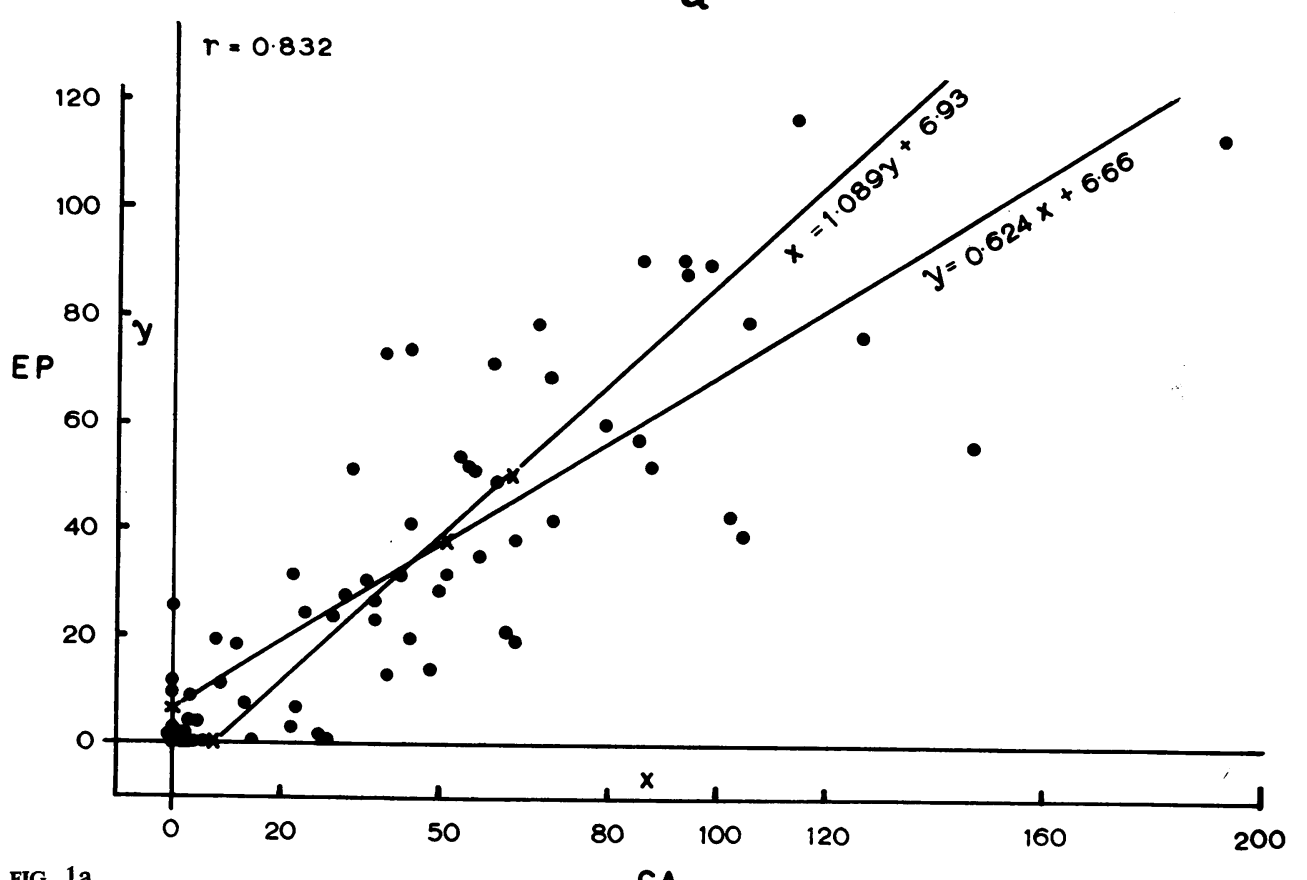

FIG. 1a.

CA

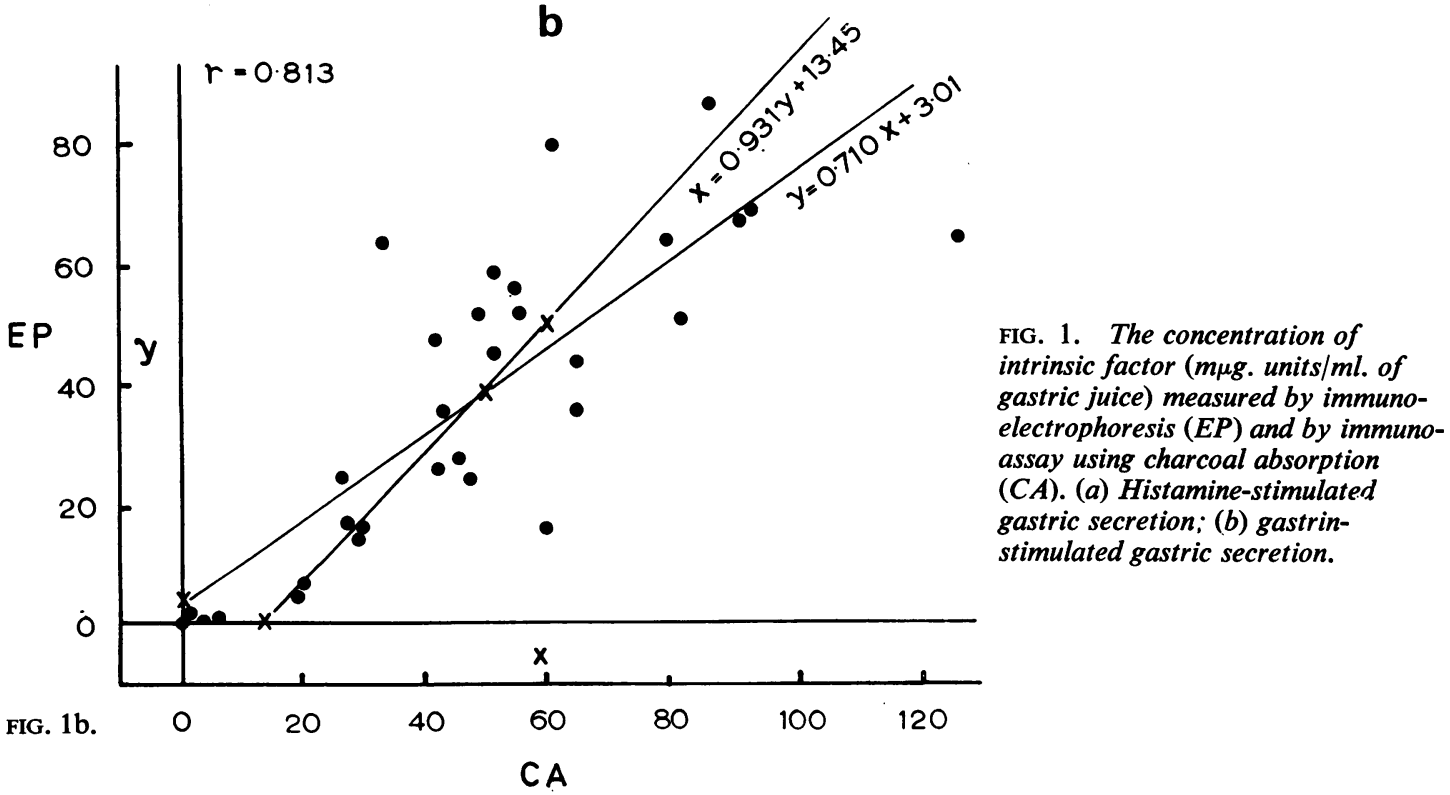

secreted between 0.1 and $9.9 \mathrm{mEq}$. $\mathrm{HCl}$, and those who secreted $10 \mathrm{mEq}$. $\mathrm{HCl}$ or more. This division was made regardless of the stimulant used. Figure 2 shows that the mean amounts of intrinsic factor secreted rose with increasing acid secretion. In all groups im- munoassay using charcoal absorption gave consistently higher values than the electrophoretic technique. By the latter method, nine patients with proven pernicious anaemia (cases 1-9, Table II) secreted from 0 to 50 units in the hour following stimulation while 


\section{TABLE I}

CORRELATION OF THE VALUES FOR THE CONCENTRATION OF INTRINSIC FACTOR MEASURED BY IMMUNOELECTROPHORESIS AND IMMUNOASSAY USING CHARCOAL ABSORPTION

\begin{tabular}{|c|c|c|c|c|}
\hline \multicolumn{2}{|c|}{ Gastric Juice Collected } & $\begin{array}{l}\text { Number of } \\
\text { Samples }\end{array}$ & $\begin{array}{l}\text { Correlation } \\
\text { Coefficient } \\
r\end{array}$ & $P$ \\
\hline \multirow{3}{*}{$\begin{array}{l}\text { A } \\
\text { B } \\
\text { C }\end{array}$} & After overnight fast & 69 & 0.689 & $<0.001$ \\
\hline & $\begin{array}{l}\text { During basal conditions } \\
\text { Following stimulation }\end{array}$ & 95 & $0 \cdot 705$ & $<0.001$ \\
\hline & $\begin{array}{l}\text { With histamine } \\
\text { With gastrin }\end{array}$ & $\begin{array}{l}68 \\
31\end{array}$ & $\begin{array}{l}0.832 \\
0.813\end{array}$ & $\begin{array}{l}<0.001 \\
<0.001\end{array}$ \\
\hline
\end{tabular}

immunoassay using charcoal absorption gave a range of 0 to 540 units per hour for the same patients.

As measured by immunoelectrophoresis, 18 out of 26 patients with achlorhydria secreted less than 170 units of intrinsic factor per hour in response to stimulation. Twelve of these 18 subjects had overt or latent pernicious anaemia and absorbed $30 \%$ or less of an oral dose of $0.5 \mu \mathrm{g}$. of ${ }^{58} \mathrm{Co}-\mathrm{B}_{12}$ measured by wholebody counting (Warner and Oliver, 1966; Callender, Witts, Warner, and Oliver, 1966) (cases 1-12, Table II). In a further two patients with latent pernicious anaemia (FD and BR, Table II), who secreted 160 and 170 units of intrinsic factor respectively, the absorption of ${ }^{58} \mathrm{Co}-\mathrm{B}_{12}$ was not reduced to this extent but was clearly enhanced by exogenous intrinsic factor. Of the

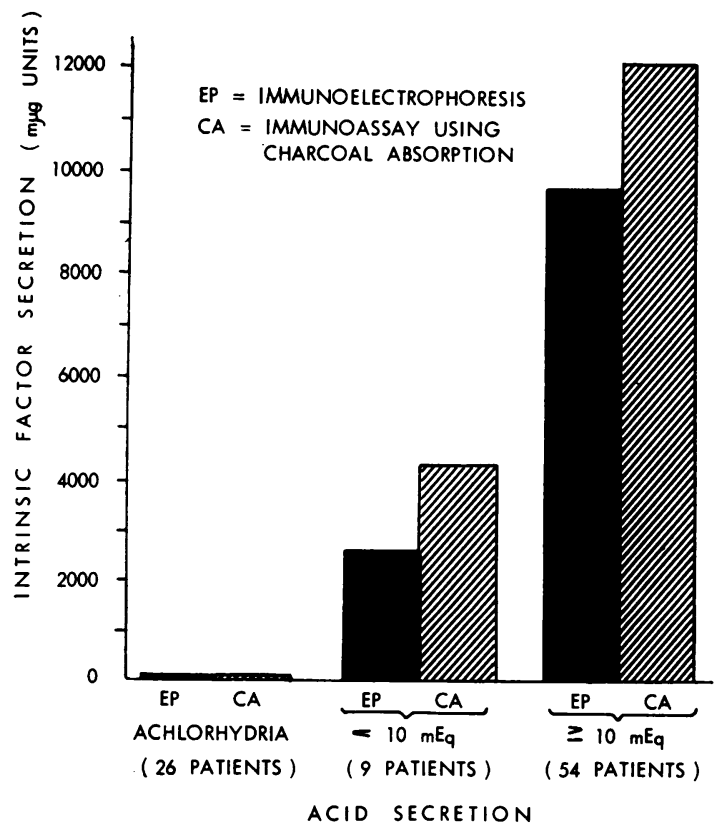

FIG. 2. The mean secretion of intrinsic factor in the hour following stimulation in three groups of patients. remaining four, two were relatives of patients with pernicious anaemia and in one of them the absorption was in the low normal range $(50 \%)$. Another patient (MM, Table II) absorbed $60 \%$ of a dose of $0.5 \mu \mathrm{g}$. ${ }^{58} \mathrm{Co}-\mathrm{B}_{12}$, but the prednisolone she was receiving for rheumatoid arthritis may have influenced the absorption (Gordin, 1959; Kristensen and Friis, 1960). This patient's serum contained antibody to intrinsic factor, and during the past four years the serum $B_{12}$ level has varied between $78 \mu \mu \mathrm{g}$. and $100 \mu \mu \mathrm{g}$. per ml. The fourth patient (WY) had a gastrojejunostomy; the gastric juice was contaminated by considerable reflux through the stoma, but the normal serum folate and the response to exogenous hog intrinsic factor showed that the low absorption of radioactive vitamin $B_{12}$ was in fact due to a lack of intrinsic factor.

By the charcoal assay 19 of 26 patients with achlorhydria secreted less than $\mathbf{5 5 0}$ units of intrinsic factor in the hour following stimulation. Twelve of these 19 subjects, with latent or overt pernicious anaemia (cases $1-12$, Table II), absorbed $30 \%$ or less of a dose of $0.5 \mu \mathrm{g} .{ }^{58} \mathrm{Co}-\mathrm{B}_{12}$ measured by whole-body counting. In another five (FD, BR, EE, MM, and WY, Table II), the intrinsic factor secretion was also within the range observed for overt or latent pernicious anaemia ( 0 to 170 units) when measured by immunoelectrophoresis. One patient (FT) who absorbed $52.8 \%$ of $0.5 \mu \mathrm{g} .{ }^{58} \mathrm{Co}-\mathrm{B}_{12}$ but showed no increased absorption with added exogenous intrinsic factor, secreted 540 units of intrinsic factor measured by charcoal assay. $\mathrm{He}$ had complete gastric atrophy and a serum $\mathrm{B}_{12}$ level of only $80 \mu \mu \mathrm{g}$. per ml.

With one exception all subjects whose total acid output was $10 \mathrm{mEq} . \mathrm{HCl}$ or more per hour secreted more than 2,400 units of intrinsic factor as measured by immunoelectrophoresis and more than 4,400 units as measured by immunoassay using charcoal absorption (Fig. 3). The exception was the 19-year-old daughter of a patient with pernicious anaemia. She appeared to have a selective impairment of intrinsic factor secretion in that she secreted $330 \mathrm{ml}$. of gastric juice containing a total of $17.3 \mathrm{mEq} . \mathrm{HCl}$ in response to gastrin. However, intrinsic factor could not be demonstrated by immunoelectrophoresis and the charcoal assay gave the low value of 3.8 units per $\mathrm{ml}$. of gastric juice and a total of 1,250 units. The serum from this girl did not contain antibodies to gastric parietal cells or to intrinsic factor.

Charcoal assays were found to give higher readings when compared with the electrophoretic method regardless of whether histamine, gastrin, or insulin had been used to enhance gastric secretion (Table III). In the single case in which Methacholine had been used as the stimulant this difference was not apparent. The difference in the results of the two assay technique; was small for specimens with a low content of intrinsic 
TABLE II

SECRETION OF INTRINSIC FACTOR IN THE HOUR FOLLOWING GASTRIC STIMULATION AND ABSORPTION OF ${ }^{58} \mathrm{CO}^{\mathrm{B}} \mathrm{B}_{12}$ IN ACHLORHYDRIC SUBJECTS

\begin{tabular}{|c|c|c|c|c|c|c|}
\hline \multirow[t]{2}{*}{ No. } & \multirow[t]{2}{*}{ Patient } & \multicolumn{2}{|c|}{ Intrinsic Factor Secretion Measured by } & \multirow{2}{*}{$\begin{array}{l}{ }^{58} \text { Co- } B_{12} \\
\text { Absorption } 1 \\
(\%)\end{array}$} & \multirow[t]{2}{*}{ Diagnosis } & \multirow[t]{2}{*}{ Comments } \\
\hline & & $\begin{array}{l}\text { Immunoelectro- } \\
\text { phoresis }\end{array}$ & $\begin{array}{l}\text { Immunoassay } \\
\text { using Charcoal } \\
\text { Absorption }\end{array}$ & & & \\
\hline
\end{tabular}

\begin{tabular}{|c|c|c|c|c|c|}
\hline $\begin{array}{r}1 \\
2 \\
3 \\
4 \\
5 \\
6 \\
7 \\
8 \\
9 \\
10 \\
11 \\
12 \\
13\end{array}$ & $\begin{array}{l}\text { I.C. } \\
\text { H.A. } \\
\text { M.C. } \\
\text { J.F. } \\
\text { J.T. } \\
\text { M.S. } \\
\text { J.C. } \\
\text { G.S. } \\
\text { W.H. } \\
\text { D.J. } \\
\text { T.W. } \\
\text { C.B. } \\
\text { F.D. }\end{array}$ & $\begin{array}{r}0 \\
0 \\
0 \\
0 \\
20 \\
20 \\
30 \\
40 \\
50 \\
0 \\
0 \\
20 \\
160\end{array}$ & $\begin{array}{r}540 \\
20 \\
70 \\
70 \\
480 \\
60 \\
30 \\
30 \\
0 \\
0 \\
480 \\
140 \\
520\end{array}$ & $\begin{array}{l}3 \\
7 \cdot 9 \\
0 \\
0 \\
0 \\
19 \cdot 5 \\
16 \\
30 \\
9 \cdot 1 \\
23 \cdot 9 \\
29 \\
19 \cdot 6 \\
42 \cdot 5\end{array}$ & $\begin{array}{l}\text { P.A. } \\
\text { P.A. } \\
\text { P.A. } \\
\text { P.A. } \\
\text { P.A. } \\
\text { P.A. } \\
\text { P.A. } \\
\text { P.A. } \\
\text { P.A. } \\
\text { L.P.A. } \\
\text { L.P.A. } \\
\text { L.P.A. } \\
\text { L.P.A. }\end{array}$ \\
\hline 14 & B.R. & 170 & 290 & $39 \cdot 8$ & L.P.A. \\
\hline $\begin{array}{l}15 \\
16 \\
17\end{array}$ & $\begin{array}{l}\text { E.E. } \\
\text { M.M. } \\
\text { W.Y. }\end{array}$ & $\begin{array}{r}0 \\
30 \\
50\end{array}$ & $\begin{array}{r}370 \\
60 \\
0\end{array}$ & $\begin{array}{l}50 \cdot 1 \\
60 \cdot 1 \\
18 \cdot 2\end{array}$ & $\begin{array}{l}\text { P.A.R. } \\
\text { Rheumatoid arthritis } \\
\text { Gastrojejunostomy } \\
\text { plus vagotomy }\end{array}$ \\
\hline $\begin{array}{l}18 \\
19\end{array}$ & $\begin{array}{l}\text { D.M. } \\
\text { F.T. }\end{array}$ & $\begin{array}{l}120 \\
350\end{array}$ & $\begin{array}{l}600 \\
540\end{array}$ & $\begin{array}{l}63 \cdot 6 \\
52 \cdot 8\end{array}$ & $\begin{array}{l}\text { P.A.R. } \\
\text { Gastric atrophy }\end{array}$ \\
\hline $\begin{array}{l}20 \\
21 \\
22 \\
23 \\
24 \\
25 \\
26\end{array}$ & $\begin{array}{l}\text { E.B. } \\
\text { E.S. } \\
\text { R.H. } \\
\text { E.P. } \\
\text { V.E. } \\
\text { W.S. } \\
\text { E.S. }\end{array}$ & $\begin{array}{r}410 \\
480 \\
510 \\
590 \\
880 \\
920 \\
1,210\end{array}$ & $\begin{array}{r}780 \\
750 \\
690 \\
1,030 \\
560 \\
0 \\
2,020\end{array}$ & $\begin{array}{l}\text { Not done } \\
51 \cdot 8 \\
65 \\
63 \cdot 9 \\
48 \\
65 \\
53.6\end{array}$ & $\begin{array}{l}\text { P.A.R. } \\
\text { Rheumatoid arthritis } \\
\text { P.A.R. } \\
\text { Gastric atrophy } \\
\text { Rheumatoid arthritis } \\
\text { Iron-deficiency anaemia } \\
\text { Myxoedema }\end{array}$ \\
\hline
\end{tabular}

Serum $\mathrm{B}_{12} 29 \mu \mu \mathrm{g} . / \mathrm{ml}$.; complete gastric atrophy; with $50 \mathrm{mg}$. H.I.F.C. ${ }^{88} \mathrm{Co}^{8} \mathrm{~B}_{38}$ absorption increased to $60.7 \%$

With $50 \mathrm{mg}$. H.I.F.C. absorption of ${ }^{68} \mathrm{Co}-\mathrm{B}_{12}$ increased to $83 \%$

Circulating G.P.C.A.B. present

On treatment with prednisolone Serum $B_{12} 240 \mu \mu \mathrm{g} . / \mathrm{ml}$.; serum folate

$7 \mathrm{~m} \mu \mathrm{g} . / \mathrm{ml}$.; serum iron $30 \mu \mathrm{g} . / \mathrm{ml}$. With 1,500 units human I.F. absorption $74 \%$

Circulating G.P.C.A.B. present

Serum $B_{18} 80 \mu \mu \mathrm{g} . / \mathrm{ml}$. No increase in ${ }^{68} \mathrm{Co}-\mathrm{B}_{12}$ absorption with $50 \mathrm{mg}$. H.I.F.C.

Circulating G.P.C.A.B. present

Circulating G.P.C.A.B. present

Atrophic gastritis

${ }^{1}$ Percentage ${ }^{58} \mathrm{Co}-\mathrm{B}_{12}$ absorption refers to the percentage of a dose of $0.5 \mu \mathrm{g} .(0.5 \mu \mathrm{c}){ }^{58} \mathrm{Co}-\mathrm{B}_{12}$ retained in the body on the 14 th day after administration, measured by whole-body counting

P.A. = pernicious anaemia

L.P.A. = latent pernicious anaemia

H.I.F.C. $=$ hog intrinsic factor concentrate

P.A.R. = relative of patient with pernicious anaemia

G.P.C.A.B. = gastric parietal cell antibody (detected by immunofluorescence)

TABLE III

CONCENTRATION OF INTRINSIC FACTOR IN GASTRIC JUICE COLLECTED FOR ONE HOUR AFTER STIMULATION

Stimulant Used

\begin{tabular}{|c|c|c|c|c|c|c|c|c|c|c|c|c|c|c|c|c|}
\hline \multicolumn{2}{|c|}{ Gastrin } & \multicolumn{3}{|c|}{ Histamine } & \multicolumn{3}{|c|}{ Gastrin } & \multicolumn{3}{|c|}{ Histamine } & \multicolumn{3}{|c|}{ Insulin } & \multicolumn{3}{|c|}{ Mecholyl } \\
\hline E.P. & $\underset{\text { Variant }}{\text { E.P. }}$ C.A. & $E . P$. & $\begin{array}{l}\text { E.P. } \\
\text { Variant }\end{array}$ & C.A. & E.P. & $\begin{array}{l}\text { E.P. } \\
\text { Variant }\end{array}$ & C.A. & E.P. & $\begin{array}{l}\text { E.P. } \\
\text { Variant }\end{array}$ & C.A. & E.P. & $\begin{array}{l}\text { E.P. } \\
\text { Variant }\end{array}$ & C.A. & E.P. & $\begin{array}{l}\text { E.P. } \\
\text { Variant }\end{array}$ & C.A. \\
\hline
\end{tabular}

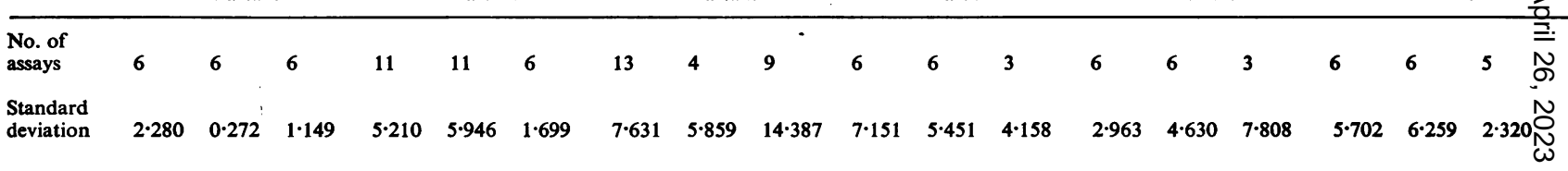

\begin{tabular}{|c|c|c|c|c|c|c|c|c|c|c|c|c|c|c|c|c|c|c|}
\hline Mean & $20 \cdot 1$ & $18 \cdot 9$ & $22 \cdot 5$ & $22 \cdot 8$ & $23 \cdot 8$ & $27 \cdot 2$ & $78 \cdot 0$ & 89.8 & $139 \cdot 3$ & 56.0 & $54 \cdot 9$ & $85 \cdot 8$ & $125 \cdot 3$ & $114 \cdot 8$ & $147 \cdot 7$ & $74 \cdot 9$ & $74 \cdot 5$ & $79 \cdot 0$ \\
\hline Statistics & & $\begin{array}{l}\mathbf{t}= \\
\mathbf{P}>\end{array}$ & $\begin{array}{l}1.934 \\
0.05\end{array}$ & $\begin{array}{l}\mathbf{t}= \\
\mathbf{P}>\end{array}$ & $\begin{array}{l}0.419 \\
0.05 .\end{array}$ & & $\begin{array}{l}\mathbf{t}= \\
\mathbf{P}>\end{array}$ & $\begin{array}{l}0.028 \\
0.05\end{array}$ & & & $\begin{array}{l}\mathbf{t}= \\
\mathbf{P}<\end{array}$ & $\begin{array}{l}27 \cdot 055 \\
0.001\end{array}$ & $\begin{array}{l}\mathbf{t}= \\
\mathbf{P}<\end{array}$ & $\begin{array}{l}4.681 \\
0.001\end{array}$ & & 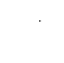 & $\begin{array}{l}t= \\
\mathbf{P}>\end{array}$ & $\begin{array}{l}1.528 \\
0.05\end{array}$ \\
\hline
\end{tabular}

E.P. = immunoelectrophoresis

C.A. = immunoassay using charcoal adsorption
E.P. Variant $=$ immunoelectrophoresis after ${ }^{57} \mathrm{Co}-\mathrm{B}_{13}$ is added to pre-incubsped mixtures of gastric juice and normal serum, and gastric juice and serum containing antibody to intrinsic factor, i.e., the sine sequence as in the charcoal assay 


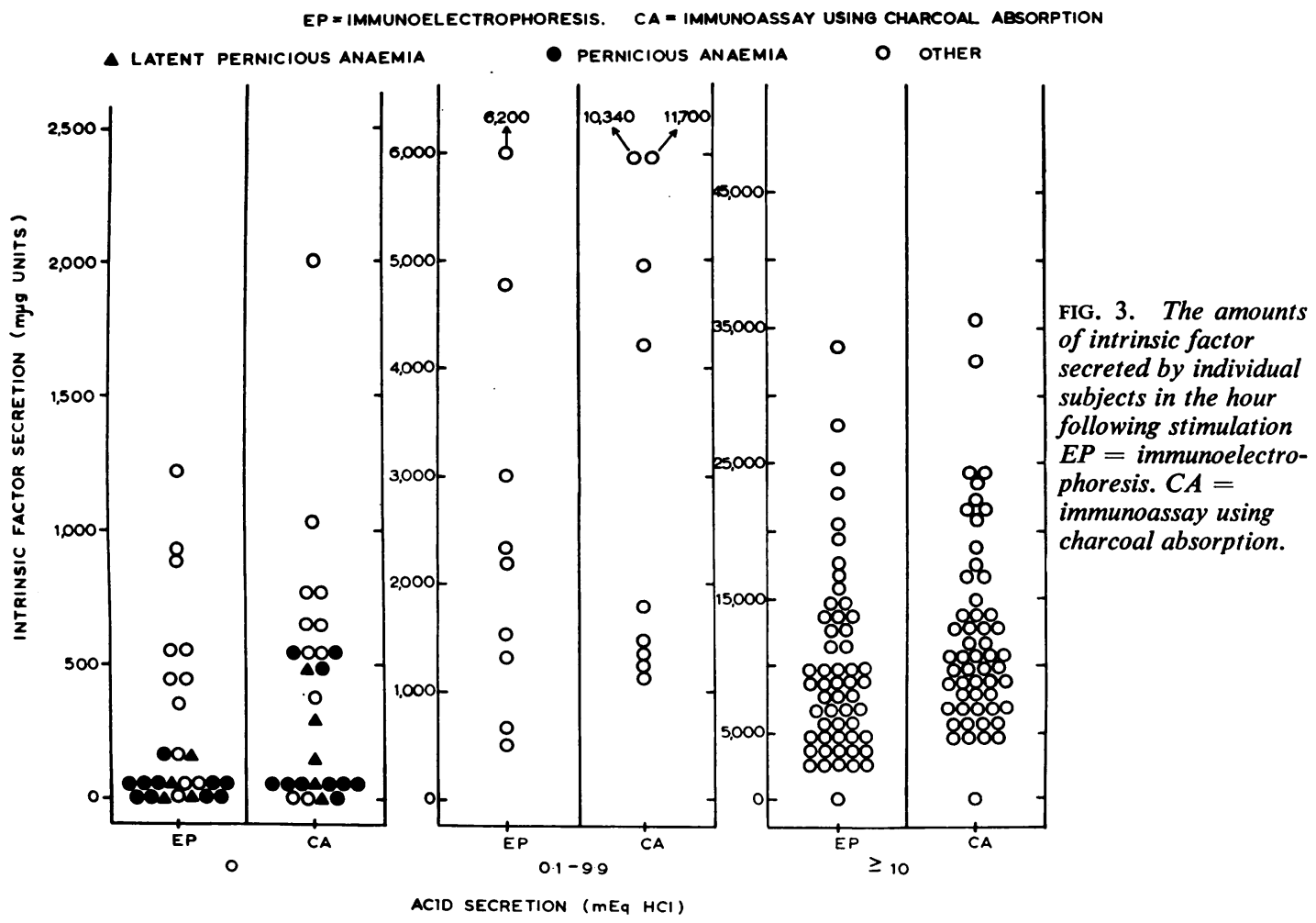

factor but considerable for those with a high content (Table III).

Further experiments were carried out to ascertain whether the difference in the results of the charcoal and electrophoretic techniques could be attributed to the fact that a different sequence of incubation of gastric juice, antibody, and vitamin $B_{12}$ was employed in the two methods. For this purpose the intrinsic factor content of six specimens of gastric juice was assayed by three methods, viz., the charcoal and electrophoretic techniques as already described and, in addition, gel electrophoresis of gastric juice incubated with serum containing antibody before the addition of ${ }^{57} \mathrm{Co}-\mathrm{B}_{12}$. The sequence of incubation in this variant of the electrophoretic technique was thus identical with that of the charcoal assay. Table III shows that the results of the electrophoretic method were not influenced by altering the sequence of incubation and that the difference between this method and the charcoal assay remained.

The correlation between the total intrinsic factor and acid secreted in the hour following stimulation with either histamine or gastrin was significant (Table IV). 
sorption tests. Such exceptions have also been noted by others (Ardeman, Chanarin, Jacobs, and Griffiths, 1966).

The degree of correlation between the results of the two methods was highest for samples of gastric juice obtained after stimulation and lowest for the overnight specimens, while samples collected during basal conditions occupied the intermediate position (Table I). This may simply reflect the relative degree of contamination of the gastric juice with swallowed saliva and mucus.

The charcoal assay gave higher values for the concentration of intrinsic factor both in single assays of 263 different samples of gastric juice and in repeated assays on single specimens. It has been suggested that the formation of an intrinsic factor-vitamin $B_{12}$ complex may make some of the antigenic sites on the intrinsic factor molecule unavailable for combination with specific antibody. This linkage might be the reason why values obtained by immunoelectrophoresis, where such a sequence is involved, are lower than those obtained by immunoassay using charcoal absorption where linkage of antigen and antibody is complete before radiovitamin $B_{12}$ is added (Ardeman, Chanarin, and Berry 1965). However, our results indicate that the availability of antigenic sites is not affected by the binding of vitamin $B_{12}$ to intrinsic factor, since the results obtained by immunoelectrophoresis were not markedly altered by allowing the antibody to interact with intrinsic factor before the addition of vitamin $B_{12}$ (Table III). We feel that the difference in the results of the two assay methods is more likely to be due to the dissimilarity of the experimental conditions of the two techniques.

Ardeman (1965), showed that there was a significant correlation between the secretion of acid and of intrinsic factor during basal conditions. Our results show that there is an even closer correlation between the secretion of acid and of intrinsic factor after stimulation of gastric secretion. Similar results were obtained by Rødbro, Christiansen, and Schwartz (1965).

Both immunoassay using charcoal absorption and immunoelectrophoresis are sensitive and reproducible methods. The former is, because of its simplicity, in our opinion the method of choice for routine clinical use. The latter is of particular value as a research technique because it can be used to measure intrinsic factor by two different principles under identical experimental conditions.

\section{ADDENDUM}

Subsequent work (Roger Hall and K.D.B.) has shown that the similarity of results obtained by the electrophoretic method and its variant was attributable to the fact that the pool of serum containing antibody to intrinsic factor fortuituously had high titres of both 'blocking' and 'binding' antibody (Schade, Abels, and Schilling, 1967).

When a serum containing a low titre of 'binding' antibody but with a high titre of 'blocking' antibody was used, the results obtained by electrophoresis were lower than those obtained by the electrophoretic variant method and by charcoal immunoassay.

The basic findings in this paper remain unchanged; however, we wish to emphasize that, to duplicate os these results, it would be necessary to use a pool of serum containing high titres of both 'blocking' and 'binding' antibody to intrinsic factor.

We are grateful to Professor P. B. Beeson for the use of facilities of his department, and to Professor P. R. Allison and Mr. W. M. Keynes, F.R.C.S. for permission to study their patients.

Miss Joy Birtles, Miss G. Huntley, Miss A. Wheeler, and Miss A. Schirmer provided technical assistance.

This work was done during the tenure of a Rhodes scholarship held by K.D.B. and a Nuffield Dominions scholarship by A.G.W., and was in part supported by a grant from the Medical Research Council.

\section{REFERENCES}

Ardeman, S. (1965). Proc. roy. Soc. Med., 58, 916.

- and Chanarin, I. (1963). Lancet, 2, 1350.

- - - and Berry, V. (1965). Brit. J. Haemat., 11, 11.

- - - _ Jacobs, A., and Griffiths, L. (1966). Blood, 27, 599.

Bardhan, K. D., Callender, S. T., and Spray, G. H. (1966). Gut, 7, 566.

Callender, S. T., Witts, L. J., Warner, G. T., and Oliver, R. (1966). Brit. J. Haemat., 12, 276.

Gordin, R. (1959). Acta med. scand., 164, 159.

Jeffries, G. H. and Sleisenger, M. H. (1963), J. clin. Invest., 42, 442. (1965). Gastroenterology, 48, 444.

Kristensen, H. P. Ø., and Friis, T. (1960). Acta med. scand., 166, 249.

Rødbro, P., Christiansen, P. M., and Schwartz, M. (1965). Lancet, 2, 1200.

Schade, S. G., Abels, J., and Schilling, R. F. (1967) J. Clin. invest., 46, N 615 ,

Wangel, A. G., and Callender, S. T. (1965a). Brit. med. J., 1, 1409. (1967). Proc. 10th Congr. europ. Soc. Haemat., Strasbourg, 1965. In the press.

Warner, G. T., and Oliver, R. (1966). Phys. in Med. Biol., 11, 83. 